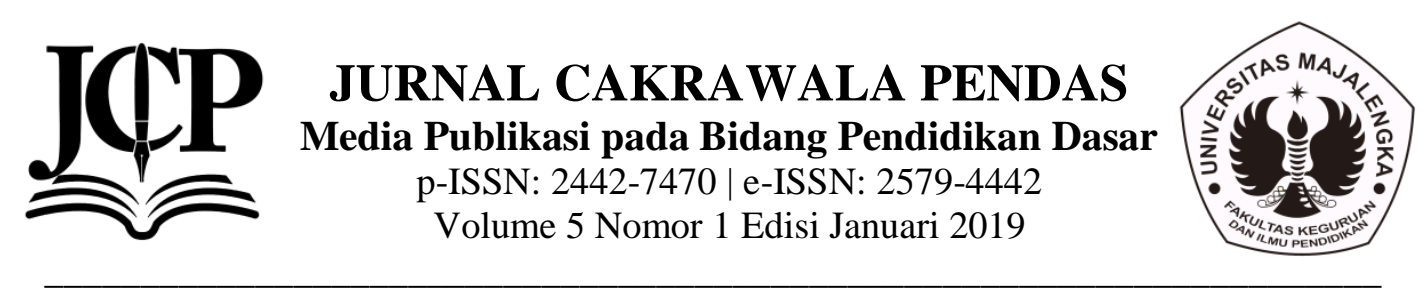

\title{
PENGEMBANGAN BAHAN AJAR IPA BERBASIS PROBLEM BASED LEARNING UNTUK SISWA KELAS V SEKOLAH DASAR
}

\author{
Rizki Umi Nurbaeti \\ rizkiuminurbaeti@gmail.com \\ Prodi PGSD FKIP Universitas Muhadi Setiabudi Jawa Tengah
}

\begin{abstract}
ABSTRAK
Penelitian ini dilatarbelakangi oleh masih banyak guru yang belum memaksimalkan pembelajaran seperti hal nya dalam mengembangkan bahan pembelajaran yang dibutuhkan. Bahan ajar berupa buku teks merupakan salah satu sumber belajar yang memiliki peran penting dalam meningkatkan kualitas pembelajaran itu sendiri. Metode penelitian ini dengan menggunakan penelitian dan pengembangan dengan prosedur penelitian yaitu (1) analisis kebutuhan, (2) Pengembangan bahan ajar (3) validasi bahan ajar yang telah dikembangkan. Hasil tes keterbacaan dari bahan ajar menunjukkan bahwa kriteria keterbacaan mudah dipahami dengan nilai rata-rata siswa menjadi $88 \%$. Secara umum dapat disimpulkan bahwa, pengembangan bahan ajar tema lingkungan sahabat kita di kelas V Sekolah Dasar berbasis Problem Based Learning dinyatakan valid.
\end{abstract}

Kata Kunci : Pengembangan Bahan Ajar IPA, Problem Based Learning. 


\section{Pendahuluan}

Kegiatan pembelajaran yang diselenggarakan di sekolah tidak terlepas dari buku pelajaran itu sendiri. Buku ajar merupakan salah satu sumber bagi penunjang pembelajaran. Bahan ajar atau materi pembelajaran secara garis besar terdiri dari beberapa aspek diantaranya aspek pengetahuan, aspek keterampilan, dan aspek sikap yang harus dikuasai oleh siswa guna mencapai standar kompetensi yang telah ditentukan. Keberadaan bahan ajar dalam kegiatan belajar mengajar sangat diperlukan untuk mendukung kegiatan tersebut. Bahan ajar merupakan salah satu komponen sistem pembelajaran yang memegang peranan penting dalam membantu siswa mencapai kompetensi itu sendiri.

Menurut Prastowo (2013: 17) mengemukakan bahwa bahan ajar pada dasarnya merupakan segala bahan (baik informasi, alat, maupun teks) yang disusun secara sistematis, yang menampilkan sosok utuh dari kompetensi yang akan dikuasai siswa dan digunakan dalam proses pembelajaran dengan tujuan perencanaan dan penelaan implementasi pembelajaran. Bahan ajar merupakan faktor eksternal bagi siswa yang mampu memperkuat motivasi dari dalam diri siswa. Bahan ajar dalam konteks pembelajaran merupakan salah satu komponen yang harus ada, karena bahan ajar yang didesain secara lengkap, artinya ada unsur media dan sumber belajar yang memadai, mempengaruhi suasana pembelajaran sehingga proses belajar yang terjadi menjadi lebih optimal.

Bahan ajar yang didesain secara bagus dan dilengkapi dengan isi dan ilustrasi yang menarik menstimulasi siswa untuk memanfaatkan bahan ajar sebagai sumber belajar. Bahan ajar menjadi sumber penting untuk menunjang proses pembelajaran. Adanya bahan ajar sekarang ini menjadi penghubung antara guru dan siswa dimana guru saat ini berperan sebagai fasilitator, sehingga penggunaan bahan ajar dapat menjembatani permasalahan keterbatasan daya serap siswa dan kemampuan guru dalam mengelola pembelajaran di kelas. Membuat bahan ajar bagi sebagian pendidik mungkin adalah hal yang mudah. Menurut Trisnaningsih (2007: 3) mengemukakan bahwa pengembangan bahan ajar merupakan salah satu bentuk dari kegiatan proses pembelajaran untuk memperbaiki atau meningkatkan kualitas pembelajaran yang berlangsung.

Bahan ajar berorientasi kepada kegiatan belajar siswa sehingga bahan ajardisusun berdasarkan kebutuhan dan motivasi siswa. Hal itu bertujuan agar siswa lebih antusias dan semangat dalam proses pembelajaran. Bahan ajar ini juga dapat digunakan siswa secara mandiri tanpa harus melibatkan guru. Bagi guru, bahan ajar ini hendaknya bisa mengarahkan guru dalam menentukan langkah-langkah pembelajaran di kelas. Pola sajian bahan ajar disesuaikan dengan perkembangan intelektual siswa sehingga mudah dipahami.

Dalam realitas pendidikan di lapangan, banyak pendidik yang masih menggunakan bahan ajar yang siap pakai, tinggal beli, instan, tanpa upaya merencanakan, menyiapkan dan menyusun sendiri. Dengan demikian resiko yang didapat adalah bahan ajar yang mereka pakai kurang menarik. Seorang pendidik dituntut kreativitasnya untuk mampu menyusun bahan ajar yang inovatif, variatif, menarik, kontekstual dan sesuai dengan tingkat kebutuhan siswa. Pendidik adalah sebagai orang yang paling paham mengenai hal ini. Maka dari itu, jika bahan ajar dibuat oleh pendidik, pembelajaran akan lebih menarik dan mengesankan bagi siswa.

Berdasarkan studi pendahuluan yang dilakukan oleh peneliti di SDN Kaligangsa Kulon 01 Kecamatan Brebes kabupaten Brebes, bahwa guru hanya menggunakan sumber yang berasal dari buku paket yang telah tersedia. Selian itu, buku tersebut belum memenuhi kebutuhan siswa serta belum 
menyesuaikan dengan karakteristik siswa. Dalam kegiatan belajar mengajar, guru hanya mengarahkan siswa untuk mencatat materi yang dibahas, setelah itu guru memberikan tugas dibagian akhir pada buku paket tersebut.

Model pembelajaran yang dipilih harus mencerminkan langkah - langkah yang sistematik yang mengandung pengertian bahwa langkah - langkah yang dilakukan guru dalam proses pembelajaran itu tersusun rapi dan logis sehingga tujuan yang ditetapkan tercapai. Salah satu strategi pembelajaran yang dapat digunakan adalah dengan menerapkan pembelajaran berdasarkan masalah atau Problem Based Learning $(P B L)$.

Menurut Yaumi (Saputra, 2016: 4) mengemukakan bahwa problem based learning (pembelajaran berbasis masalah) merupakan metode pembelajaran dengan pendekatan pembelajaran siswa pada masalah autentik sehingga siswa dapat menyusun pengetahuannya sendiri, menumbuh kembangkan keterampilan yang lebih tinggi dan inquiry, memandirikan siswa dan meningkatkan kepercayaan diri sendiri.

Menurut Rusman (2012:76) mengemukakan model pembelajaran $P B L$ merupakan salah satu pendekatan pembelajaran yang digunakan untuk merangsang berpikir tingkat tinggi siswa dalam situasi yang berorientasi pada masalah dunia nyata. Dalam pembelajaran ini siswa diminta mengerjakan masalah nyata yang ditemukan dalam kehidupan sehari-hari, dengan maksud untuk menyusun pengetahuan mereka sendiri, mengembangkan kemandirian dan percaya diri. Tugas guru disini mengorientasikan siswa kepada masalah autentik dan memfasilitasi dialog siswa, juga melakukan tanya jawab selebihnya siswa yang aktif dalam proses pembelajaran. Sehingga diharapkan pembelajaran menjadi lebih bermakna. Pelaksanaan pembelajaran PBL tentunya juga membutuhkan sarana yang sesuai agar pelaksanaan pembelajaran bisa lebih baik.

Berdasarkan pemaparan di atas, peneliti perlu kiranya untuk mengembangkan bahan ajar berbasis model problem based learning untuk kelas V Sekolah dasar.

\section{Metode Penelitian}

Penelitian ini menggunakan penelitian R \& D (Reserch and Development) menurut Borg \& Gall. Menurut Borg \& Gall (2008), menurut Sumantri (2018) menyatakan bahwa pada dasarnya penelitian dan pengembangan adalah proses yang digunakan untuk mengembangkan dan memvalidasi produk yang dikembangkan. Pengembangan bahan ajar dengan tema lingkungan sahabat kita di kelas V Sekolah Dasar Pembelajaran berbasis problem based learning adalah penelitian pengembangan yang diarahkan untuk menghasilkan bahan ajar yang telah dikembangkan berdasarkan problem based learning. Penelitian ini dilakukan pada siswa kelas lima Sekolah Dasar yang yang dilakukan di SDN Kaligangsa Kulon 01 Kecamatan Brebers Kabupaten Brebes pada bulan september 2018. Penelitian ini dilakukan dengan mengembangkan bahan ajar secara sistematis. Langkah-langkah ini adalah (1) Studi Awal, (2) Perencanaan, (3) Desain Produk, dan (4) Validitas Produk,

Langkah (1) adalah langkah pertama penelitian pengembangan. Kegiatan yang dilakukan dalam studi pendahuluan ini adalah studi literatur, identifikasi kebutuhan, dan identifikasi masalah. Langkah (2), pada tahap perencanaan, peneliti melakukan beberapa kegiatan termasuk: a) Memilih model problem based learning, yang diharapkan efektif dalam penggunaan bahan ajar berdasarkan model pembelajaran, b) Menyiapkan bahan ajar berdasarkan problem based learning, c) Membuat instrumen kelayakan produk. 
Pada tahap ini persiapan instrumen penilaian diberikan kepada ahli materi/ahli konten, dan ahli bahasa. Langkah (3) mendesain produk yang dikembangkan, hasil pengembangan dari penelitian ini adalah bahan ajar untuk tema lingkungan sahabat kita berbasis problem based learning yang dilengkapi dengan penambahan bahan pelengkap, gambar, dan lembar aktivitas siswa yang melibatkan penyelesaian masalah. Kemudian langkah (4) adalah langkah langkah validasi produk yang dilakukan para ahli.

\section{Hasil Penelitian}

Hasil analisis kebutuhan instruksional yang diperoleh dari analisis kebutuhan pendidik dan siswa antara lain: materi yang dikembangkan adalah dalam bentuk buku, bahannya praktis atau tidak hanya dihafal, kegiatan belajar melibatkan semua aspek perkembangan siswa dalam menyelesaikan permasalahan yang berkaitan dengan kehidupan seharihari.

Rekapitulasi hasil penilaian validator yang diperoleh dari ahli materi dan ahli bahasa pada produk yang dikembangkan dalam bentuk bahan ajar tema lingkungan sahabat kita berdasarkan problem based learning dapat dilihat pada tabel di bawah ini:

Tabel 1. Rekapitulasi Hasil Penilaian

\begin{tabular}{|c|c|}
\hline \multicolumn{2}{|l|}{ Validator } \\
\hline Aspek & Skor \\
\hline $\begin{array}{l}\text { Kelayakan penampilan buku } \\
\text { secara menyeluruh }\end{array}$ & $86,90 \%$ \\
\hline Isi buku & $85,80 \%$ \\
\hline $\begin{array}{l}\text { Kelayakan kegiatan pembelajaran } \\
\text { berbasis PBL }\end{array}$ & $82,35 \%$ \\
\hline Menu tambahan & $87,5 \%$ \\
\hline Linguistik & $75 \%$ \\
\hline Presentasi & $85 \%$ \\
\hline Rata-rata & $83,76 \%$ \\
\hline
\end{tabular}

Tes keterbacaan pada bahan ajar tema lingkungan sahabat kita berdasarkan Pembelajaran Berbasis masalah yang dilakukan pada 39 siswa di SDN
Kaligangsa Kulon 01 Kecamatan Brebers Kabupaten Brebes. Hasil analisis uji keterbacaan bahan ajar yang telah dikembangkan dalam penelitian ini mendapatkan hasil dengan nilai rata-rata siswa adalah 88\%. Berdasarkan skor, kategori buku bacaan mudah dipahami.

Melihat dari rekapitulasi hasil validasi validator yang memperoleh skor $83,76 \%$ dengan kategori sangat valid dan tes keterbacaan mendapatkan $88 \%$ dengan kategori buku mudah dipahami, produk yang telah dikembangkan dalam bentuk tema bahan ajar lingkungan sahabat kita berdasarkan problem based learning dapat dilanjutkan dan digunakan ketika pembelajaran sekolah dasar kelas 5 .

\section{Kesimpulan}

Berdasarkan hasil penelitian dan pembahasan, dapat disimpulkan bahwa pengembangan produk berupa bahan ajar lingkungan sahabat kita berbasis Problem Based Learning untuk siswa kelas empat sekolah dasar, dikembangkan berdasarkan analisis kebutuhan pendidik dan siswa. Dari hasil analisis kebutuhan, maka prinsip-prinsip pengembangan bahan ajar diformulasikan untuk selalu menjaga lingkungan berdasarkan problem based learning yang pada umumnya bahan ajar berisi materi yang praktis dan kegiatan pembelajaran yang melibatkan kegiatan praktis serta mendorong siswa untuk memiliki kemampuan berpikir tingkat tinggi.

Produk-produk yang telah dikembangkan telah divalidasi oleh para ahli materi dan ahli bahasa dan tes keterbacaan telah dilakukan pada 39 siswa SDN Kaligangsa Kulon 01 Kecamatan Brebers Kabupaten Brebes. Hasil validasi keseluruhan dari kedua ahli tersebut memperoleh persentase $83,76 \%$ dengan kategori sangat valid dan uji keterbacaan memperoleh hasil 88,00 dengan kategori yang mudah dipahami. Berdasarkan kriteria ini, bahan ajar tema lingkungan sahabat kita berdasarkan Problem Based Learning cocok untuk 
digunakan sebagai buku pendamping dalam belajar di kelas lima Sekolah Dasar.

\section{Daftar Pustaka}

Prastowo, Andi. 92013) Panduan Kreatif Membuat Bahan Ajar Inovatif (Yogyakarta:Diva Press.

Trisnaningsih, (2007).Pengembangan Bahan Ajar Untuk Meningkatkan Pemahaman Materi Mata Kuliah Demografi Teknik. Jurnal Ekonomi \& Pendidikan. h. 3

Rusman, (2012). Model - Model Pembelajaran. Raja Grafindo Persada: Jakarta

Saputra, dudu S. (2016). Pengaruh metode pembeajaran dan berpikir kritis terhadap kemampuan menulis argumentasi. Jurnal Pendidikan Dasar Program Pascasarjana Universitas Negeri Jakarta

M. D. Gall, J. P. Gall, and W. R. Borg. (2007). Educational Research: An Introduction (8th Edition). New York: Longman.

R. Rachmadtullah, Z. Ms, and M. S. Sumantri. (2018). "Development of computer - based interactive multimedia : study on learning in elementary education," Int. J. Eng. Technol., vol. 7, no. 4, pp. 20352038.

M. S. Sumantri, A. W. Prayuningtyas, R. Rachmadtullah, and I. Magdalena, "The Roles of Teacher-Training Programs and Student Teachers' SelfRegulation in Developing Competence in Teaching Science," Adv. Sci. Lett., vol. 24, no. 10, pp. 7077-7081, Oct. 2018. 